\title{
Moderating the Relationship Between Student's Gender and Science Motivation
}

\author{
Wajeeh Daher ${ }^{1,2^{*}}$, Essa Alfahel ${ }^{3,4}$, Ahlam Anabousy $^{5}$ \\ ${ }^{1}$ An-Najah National University, Nablus, PALESTINE \\ 2 Al-Qasemi Academic College of Education, Baqa, ISRAEL \\ ${ }^{3}$ Kaye Academic College of Education, Beer-Sheva, ISRAEL \\ ${ }^{4}$ Achva Academic College of Education, Shikmim, ISRAEL \\ ${ }^{5}$ Kibbutzim College of Education, Technology and the Arts, Tel-Aviv, ISRAEL
}

Received 24 January 2021 - Accepted 19 March 2021

\begin{abstract}
Researchers are interested in students' motivation to learn science as it impacts other aspects of students' learning. One aspect of this motivation is the gender issue, how it impacts student's motivation and how it is mediated and moderated by other educational variables. The issue of gender impact on motivation has been studied for more than two decades, which makes the present research interested in studying how background variables as student's ability, school level and teacher's gender moderate the relationship between student's gender and the different components of science motivation. The research design is that of moderation design through multiple regression. The sampling was a cluster sampling. The instrument used was the socialcognitive motivation questionnaire, and data analysis was done using regression and moderation analysis in SPSS 25 Statistical Package. Eight hundred, thirty-seven students, from the primary, middle and secondary schools participated in the research. The research results indicated that each of the three variables moderated between student's gender and part of the components of science motivation. The research concludes that the science teaching methods need to be diverse to fit both male and female science students, which could assist the learning of science in the secondary school from the two genders. Moreover, utilizing different teaching methods would support all ability -level students. In addition, holding workshops for teachers that discuss the gender issue in science education can help address this issue.
\end{abstract}

Keywords: science motivation, student's gender, teacher's gender, student's ability, school level, moderation of science motivation

\section{INTRODUCTION}

Researchers are interested in different constructs of students' learning, especially the affective and psychological constructs (Daher, 2011; Daher, Anabousy, \& Jabarin, 2018). One such construct is students' motivation, where different aspects of this construct have attracted researchers' attention. One such aspect is the constructs that influence students' motivation, while a second aspect is the variables that are affected by motivation. Researchers who were interested in the first aspect pointed at the context or environment as influencing students' motivation. One such environment is e-learning (e.g., Lin, Chen, \& Liu, 2017), while another is game-based learning (Say \& Bag,
2017). Researchers who were interested in the second aspect reported the different constructs affected by motivation (e.g., Bal-Taştan et al., 2018). Such constructs are academic outcomes and achievement (e.g., Areepattamannil, Freeman, \& Klinger, 2011), students' processing style (e.g., Nolen \& Haladyna, 1990), performance and success (Obrentz, 2011), self-regulation in science learning (Velayutham, Aldridge, \& Fraser, 2012), participation in science fairs (Dionne, Reis, Trudel, Guillet, Kleine, \& Hancianu, 2012), the preferred academic subject (Lee, 2017) and future career- related choices (Taskinen, Schütte, \& Prenzel, 2013). In addition, motivation affects the relationships between variables by being a mediating or moderating variable. Bonney et al. (2005), in considering the relation between motivation

(c) 2021 by the authors; licensee Modestum. This article is an open access article distributed under the terms and conditions of the Creative Commons Attribution License (http://creativecommons.org/licenses/by/4.0/).

\daherwajeeh@gmail.com (*Correspondence) $\$ eisaalfahel@gmail.com $\$ ahlamanabosi@gmail.com 


\section{Contribution to the literature}

- The study investigates student's ability, school level and teacher's gender as moderators of the relationship between student's gender and the different components of science motivation.

- The study considers students' motivation in three school levels: primary, middle and high.

- The study concludes the need for diverse teaching methods to be implemented in the science classroom.

and achievement, proposed two possible ways. The first way is that motivational beliefs can mediate the relation between the instructional strategy and achievement. The second way is that the instructional strategy fits students with specific motivational beliefs and thus impact the relationship between instructional strategy and achievement. Here, motivational beliefs play the role of a moderating variable rather than a mediating one.

\section{Motivational Constructs}

Researchers described different motivational constructs that could impact students' learning of science. These factors are: efficacy, task value or science learning value, interest to learn science, attitudes towards learning science, and achievement goals (Bonney et al., 2005; Eccles, Wigfield, \& Schiefele, 1998; Ng, Soon, \& Fong, 2010; Tuan, Chin, \& Shieh, 2005). Selfefficacy refers to students' beliefs and social cognitive judgments of one's capabilities to do the tasks in the classroom (Bandura, 1997), which impact how students are engaged with science learning or activities. Task value beliefs are concerned with the utility of the subject matter domain, in this case science, and are related to the extent to which the task is useful, enjoyable, or relates to one's self-image of value (Glynn, Taasoobshirazi, \& Brickman, 2009; Palmer, 2007). Interest to learn science refers to an individual's attraction to a specific activity or domain, including emotional constructs (Pintrich \& Schunk, 2002). Finally, students' achievement goals could be mastery goals (goals focused on learning and understanding), performance goals (goals focused on outperforming others) or achievement goals (goals focused on getting high marks).

In addition, Tuan et al. (2005), in a review of learning motivation studies, reported a variety of motivation constructs, such as active learning strategies, selfperceptions of ability, effort, intrinsic goal orientation, task value, self-efficacy, test anxiety, self-regulated learning, task orientation and learning strategies. $\mathrm{Ng}$, Soon and Fong (2010) considered attributions as a motivational factor. According to the attribution theory (Weiner, 1979), students who believe that success is related to effort will be more likely to use effort than those who believe that success is due to inherent ability. In the present paper we used the motivational constructs in Glynn, Brickman, Armstrong, and Taasoobshirazi (2011), which included intrinsic motivation and personal relevance, self-efficacy and assessment anxiety, selfdetermination, career motivation, and grade motivation.
Glynn et al. (2011) describe intrinsic motivation as involving the satisfaction in learning science for its own sake; self-determination as referring to the control students believe they have over their learning of science, self-efficacy as referring to students' belief that they can accomplish well in science and extrinsic motivation as involving learning science to an end, such as a career or a grade. Glynn et al. say that these components constitute a componential model of motivation derived from social cognitive theory and that they contribute positively to the arousal, direction, and sustainment of students' science-learning behaviour.

\section{Factors that Influence Science Motivation}

Empirical research has been interested in different aspects of motivation to learn science as the context. Here, researchers reported that the teacher influences the motivation level of science students (Aktan, 2019). In addition, researchers were interested in how background variables, such as gender, affect this level (e.g., Debacker \& Nelson, 2000). Chow and Yong (2013) used a similar questionnaire to the present study (Glynn, Taasoobshirazi, \& Brickman, 2009) to investigate secondary school students' motivation and achievement in combined science. Results indicated that the participants showed a moderate level of intrinsic motivation, personal relevance, self-determination and self-efficacy and a high level of extrinsic motivation and assessment anxiety in learning-combined science. Furthermore, the results showed significant positive correlations between students' motivational orientations and science achievement.

Below, we will describe studies that examined how student's ability, school level and teacher's gender, as background variables, affect students' motivation to learn science. Relatively little research has studied the moderation of background or educational variables on the relation between gender and motivation to learn science, which points at the need to do so. We will first describe the literature that studied how each of the variables (gender, ability, school level, teacher's gender) affect motivation in science, and then describe previous attempts to study variables that moderate or mediate the relationship between student's gender and his/her motivation to learn science.

The literature about gender in motivation in general and science motivation in particular is combined. Meece, Glienke, and Burg (2006) reviewed the literature to examine how gender shaped achievement motivation. 
They concluded that boys reported stronger ability and interest beliefs in mathematics and science, whereas girls had more confidence and interest in language arts and writing. Debacker and Nelson (2000) found that girls had higher scores on perceived instrumentality and pleasing the teacher than did boys. Obrentz (2011) found that females reported lower intrinsic motivation, personal relevance, self-efficacy and critical thinking, and higher assessment anxiety, rehearsal and organization. Selfefficacy predicted performance for males and females, while self-determination, help-seeking and study environment also predicted female success.

More recent results are also combined. Chow and Yong (2013) found a significant difference between boys and girls in assessment anxiety, while there were no other differences in motivational beliefs due to gender. Chumbley, Haynes, and Stofer (2015) found no significant correlations between gender and motivation to learn science. At the same time, they found that females generally had higher self-determination and grade motivation than males. Thomas (2017) examined how teachers' implicit science-is-male stereotypes influence students' motivation to learn science. They found that these stereotypes are positively related with males' self-concept and intrinsic value but negatively associated with females' motivational beliefs.

Glynn, Taasoobshirazi, and Brickman (2009) used the first version of the questionnaire used in the present study to examine differences in science and non-science majors' motivation that could be attributed to gender. They reported that there were no significant differences in total scores of science motivation due to gender; however, the scores of the self-efficacy and assessment anxiety scale were higher among the men than the women, suggesting that the men had more confidence and less anxiety than the women. The scores on the selfdetermination scale, however, were higher among the women than the men, suggesting that the women believed they had more control over their learning than the men. The scores on the career motivation scale were slightly higher among the women than the men, but the effect size was below the criterion of 0.20 . There were no significant differences due to gender on scores on the intrinsic motivation and personal relevance scale or the grade motivation scale.

The above combined results about the effect of gender on science motivational beliefs could indicate that some variables moderate between gender and motivation, which indicates the necessity of studying this moderation. In the present paper we study the moderation of ability, school level and teacher's gender between students' gender and their motivational beliefs.

Some research has paid attention to the impact of ability on science motivation, the literature shows positive relationship between ability and performance in science subjects. Debacker and Nelson (2000) say that along with goals, students' perceptions of their ability to perform science tasks affect motivation to learn. Obrentz (2011) found that high course performers reported the highest levels of motivation and learning strategy use. Chow and Yong (2013) also found significant differences in motivational beliefs towards learning science between high ability and low ability students in favor of high ability students.

School level has been studied as impacting science motivation. Generally, researchers found that students' motivation decline over time. Freeman and Anderman (2005) reviewed the motivation research to emphasize that students' personal goals can change over time, with many students showing a decline in mastery goal orientation. They also emphasize that research has also shown a tendency for students' mastery goal orientation to decrease following the transition from primary into middle school. Specifically, Jacobs, Lanza, Osgood, Eccles, and Wigfield (2002) found that grade is a significant factor in motivation and engagement, where the transition from junior high to middle high can result in declines in motivation. Martin (2007) found that although both boys' and girls' motivation is lower in middle high school, only girls' motivation is relatively higher in senior high school. On the other hand, Chumbley, Haynes, and Stofer (2015) found no significant correlations between gender or grade level and motivation to learn science The previous results indicate that the grade issue is an important element to include in research on academic motivation and engagement (Martin, 2007), which the present research intends to follow up. Here, we consider the impact of the grade on the relation between gender and science motivation; i.e., as a moderating variable.

Little research has been done regarding the issue of teacher's gender in science motivation. Martin and Marsh (2005) targeted the gender-stereotypic model that states that boys fare better academically in classes taught by males, while girls fare better in classes taught by females. Their results proved otherwise; they found that, in support of the gender-invariant model, academic motivation does not significantly vary as a function of the teacher's gender, and in terms of academic motivation and engagement, boys do not fare any better with male teachers than female teachers.

\section{Moderation and Mediation of Gender Differences in Science Motivation}

Trying to explain gender differences in science motivation, researchers looked at the moderation and mediation of these differences. Meece and Jones (1996) reported that differences in science motivation are moderated by ability, race, and classroom context. As to the ability level, they found that in the low ability group only; boys reported a stronger mastery goal orientation than did girls. Middleton and Midgley (1997) found that ethnicity moderates between gender and science 
motivation, where African American girls reported a stronger learning goal orientation than African American boys. No differences in goal orientations were found for European American students. Moreover, King (2016) found that gender differences in science motivation were mediated by peers' attitude toward school. Boys perceived their friends to have more negative attitudes toward science, where these perceptions were associated with boys' lower levels of motivation. In addition, Chung and Chang (2017) found that educational games reduce the effect of gender on learning achievement and motivation.

\section{Research Rationale and Goals}

Researchers have been interested in students' motivation in general (Meece et al., 2006) and students' motivation to learn science in particular (Glynn, Brickman, Armstrong, \& Taasoobshirazi, 2011) as it influences students' learning of science and success in their learning. One of the issues to which researchers paid attention in science motivation is the issue of gender. Trying to understand this issue in students' motivation to learn science helps understand how to affect positively students' motivation to learn science from the two genders. Research related to the gender issue in science motivation is combined, as there is no clear trend regarding this relation, which indicates the need to study variables that could mediate or moderate the relation. In the present research, we consider student's ability, grade level and teacher's gender, as moderators of the relation between gender and motivation. Little research has focused on the previous variables as moderators between student gender and motivation. Thus, the present research will shed more light on the gender issue in science motivation, enabling educators to deepen their understanding of this issue and of the role of the studied moderators in this issue. This would provide science teachers with means to attempt to affect positively students' motivation to learn science from the two genders. This could be done, for example, by taking into consideration the undesired impact of the moderators, and thus trying to lessen it.

Studies in motivation were based on different theories, where one such theory is the social cognitive theory, developed by Bandura (1986) and extended by others (e.g., Pajares \& Schunk, 2001). This theory considers human activity as reciprocal interactions among personal characteristics, environmental contexts, and behaviors (Glynn et al., 2011). This consideration makes it appropriate for considering relations and moderation of relations between variables related to personal characteristics, as the student's gender, and environmental variables as grade and teacher's gender. Thus, in the present study, we adopt this theory to study the moderation between gender and motivation to learn science.

\section{Research Question}

Do student's background variables (student's ability, school level and teacher's gender) moderate between student's gender and motivation to learn science?

\section{METHODOLOGY}

\section{Data Sample}

The sampling was a cluster one. The population was first divided into three clusters: primary school students, middle school students and high school students. Afterwards, random sampling was applied to each cluster of population.

Table 1 describes the frequencies of the research sample regarding the four background variables: Student gender (SGender), ability, teacher gender (Tgender) and school level (ScLevel).

\section{Data Collecting Tools}

In the present study, we used the questionnaire which Glynn et al. (2011) developed to assess five socialcognitive motivation components: intrinsic motivation and personal relevance, self-efficacy and assessment anxiety, self-determination, career motivation, and grade motivation. The questionnaire distributed to the participants is composed of two parts. The first part gathers background information about the respondent: Student gender, ability in science and teacher's gender. Each of the gender variables has two values, while the variable ability in science has three values: weak, medium and strong. The second part of the questionnaire is composed of 25 items that represent the five components of science motivation, where each component is composed of 5 items. Following are examples on each component: intrinsic motivation (e.g., I am curious about discoveries in science), selfdetermination (e.g., I study hard to learn science), selfefficacy (e.g., I am sure I can learn science), career motivation (e.g., My career will involve science), and grade motivation (e.g., I think about the grade I will get in science). Students respond to each item on a rating scale of temporal frequency: never (1), rarely (2), sometimes (3), often (4), or always (5). Exploratory factor analysis performed by Glynn et al. (2011) showed All of the items met the criterion of loading at least 0.35 on their respective factor (Tabachnick \& Fidell, 2000). The eigenvalue and percent of variance explained by each factor were: intrinsic motivation $(8.83,35.33 \%)$, career motivation $(2.83,11.31 \%)$, self-determination (2.21, $8.84 \%)$, self-efficacy $(1.78,7.13 \%)$, and grade motivation $(1.26,5.03 \%)$. The cumulative percent of variance explained by the factors was $67.64 \%$. The confirmatory factor analysis yielded fit indices of $\chi 2 / \mathrm{df}=2.77, \mathrm{SRMR}=$ 0.04, GFI $=0.93, \mathrm{CFI}=0.91$, RMSEA $=0.07$, which indicates that the measurement model fits the data well, 
Table 1. Frequencies of the research sample according to the background variables

\begin{tabular}{|c|c|c|c|c|c|c|c|}
\hline & & & & primary & middle & high & \\
\hline \multirow[t]{12}{*}{ male } & \multirow[t]{3}{*}{ low } & \multirow[t]{2}{*}{ Teacher gender } & male & 2 & 1 & 6 & 9 \\
\hline & & & female & 2 & 6 & 8 & 16 \\
\hline & & \multicolumn{2}{|l|}{ Total } & 4 & 7 & 14 & 25 \\
\hline & \multirow[t]{3}{*}{ middle } & \multirow[t]{2}{*}{ Teacher gender } & male & 2 & 3 & 19 & 24 \\
\hline & & & female & 35 & 36 & 31 & 102 \\
\hline & & \multicolumn{2}{|l|}{ Total } & 37 & 39 & 50 & 126 \\
\hline & \multirow[t]{3}{*}{ high } & \multirow[t]{2}{*}{ Teacher gender } & male & 1 & 11 & 18 & 30 \\
\hline & & & female & 58 & 65 & 32 & 155 \\
\hline & & \multicolumn{2}{|l|}{ Total } & 59 & 76 & 50 & 185 \\
\hline & \multirow[t]{3}{*}{ Total } & \multirow[t]{2}{*}{ Teacher gender } & male & 5 & 15 & 43 & 63 \\
\hline & & & female & 95 & 107 & 71 & 273 \\
\hline & & \multicolumn{2}{|l|}{ Total } & 100 & 122 & 114 & 336 \\
\hline \multirow[t]{12}{*}{ female } & \multirow[t]{3}{*}{ low } & \multirow[t]{2}{*}{ Teacher gender } & male & 1 & 1 & 3 & 5 \\
\hline & & & female & 1 & 2 & 7 & 10 \\
\hline & & \multicolumn{2}{|l|}{ Total } & 2 & 3 & 10 & 15 \\
\hline & \multirow[t]{3}{*}{ middle } & \multirow[t]{2}{*}{ Teacher gender } & male & 1 & 10 & 8 & 19 \\
\hline & & & female & 36 & 41 & 69 & 146 \\
\hline & & \multicolumn{2}{|l|}{ Total } & 37 & 51 & 77 & 165 \\
\hline & \multirow[t]{3}{*}{ high } & \multirow[t]{2}{*}{ Teacher gender } & male & 1 & 7 & 28 & 36 \\
\hline & & & female & 149 & 66 & 70 & 285 \\
\hline & & \multicolumn{2}{|l|}{ Total } & 150 & 73 & 98 & 321 \\
\hline & \multirow[t]{3}{*}{$\overline{\text { Total }}$} & \multirow[t]{2}{*}{ Teacher gender } & male & 3 & 18 & 39 & 60 \\
\hline & & & female & 186 & 109 & 146 & 441 \\
\hline & & \multicolumn{2}{|l|}{ Total } & 189 & 127 & 185 & 501 \\
\hline \multirow[t]{12}{*}{ Total } & low & Teacher gender & male & 3 & 2 & 9 & 14 \\
\hline & & & female & 3 & 8 & 15 & 26 \\
\hline & & Total & & 6 & 10 & 24 & 40 \\
\hline & middle & Teacher gender & male & 3 & 13 & 27 & 43 \\
\hline & & & female & 71 & 77 & 100 & 248 \\
\hline & & Total & & 74 & 90 & 127 & 291 \\
\hline & high & Teacher gender & male & 2 & 18 & 46 & 66 \\
\hline & & & female & 207 & 131 & 102 & 440 \\
\hline & & Total & & 209 & 149 & 148 & 506 \\
\hline & Total & Teacher gender & male & 8 & 33 & 82 & 123 \\
\hline & & & female & 281 & 216 & 217 & 714 \\
\hline & & Total & & 289 & 249 & 299 & 837 \\
\hline
\end{tabular}

and thus provides evidence of questionnaire construct validity.

Face validity was performed through requesting 30 students, 10 from each school level, to answer the questionnaire and ask for clarification if needed. Formulation of 4 items was changed to make them clearer. Content validity was performed by requesting university lectures in education and psychology to assess the items in each construct in the questionnaire regarding their measuring of the construct. The experts agreed that the items in each construct are relevant and clear. The reliabilities (internal consistencies) of the scales, assessed by Cronbach's alphas, according to Glynn et al. (2011), were: career motivation (0.92), intrinsic motivation (0.89), self-determination (0.88), selfefficacy (0.83), and grade motivation (0.81). The Cronbach's alpha of all 25 items was 0.92 . These values are very good according to DeVellis (2003).

\section{Data Analysis Tools}

To examine for moderation we followed Statistics Solutions (2013) who recommended that a multiple linear regression needs to be conducted in order to analyze moderation effects. The independent variables of the regression are the independent variables of the research (in our case student's gender), moderator (in our case one of the background variables: student's ability, the school level or the teacher's gender), and the interaction between independent variable and moderator. The interaction is created by multiplying independent variable and moderator after both have been centered to have a mean of 0 . The dependent variable of the regression is dependent variable (in our case the type of motivational belief). If the interaction is significant, then moderation is supported. 
Table 2. Means, standard deviations and $t$ values for the components of science motivation according to student gender

\begin{tabular}{|c|c|c|c|c|c|c|}
\hline & Student gender & $\mathrm{N}$ & Mean & SD & t value & $\mathrm{p}$ value \\
\hline \multirow[t]{2}{*}{ Intrinsic Motivation } & male & 336 & 3.815 & .691 & \multirow{2}{*}{-4.825} & \multirow{2}{*}{.000} \\
\hline & female & 500 & 4.048 & .682 & & \\
\hline \multirow[t]{2}{*}{ Self-efficacy } & male & 336 & 3.422 & .709 & \multirow{2}{*}{-2.613} & \multirow{2}{*}{.009} \\
\hline & female & 500 & 3.556 & .739 & & \\
\hline \multirow[t]{2}{*}{ Self-determination } & male & 335 & 3.817 & .876 & \multirow{2}{*}{-5.221} & \multirow{2}{*}{.000} \\
\hline & female & 502 & 4.128 & .660 & & \\
\hline \multirow[t]{2}{*}{ Career motivation } & male & 336 & 3.627 & 1.131 & \multirow{2}{*}{-4.628} & \multirow{2}{*}{.000} \\
\hline & female & 502 & 3.976 & 1.030 & & \\
\hline \multirow[t]{2}{*}{ Grade motivation } & male & 336 & 3.844 & .716 & \multirow{2}{*}{-5.337} & \multirow{2}{*}{.000} \\
\hline & female & 501 & 4.096 & .640 & & \\
\hline \multirow[t]{2}{*}{ General motivation } & male & 335 & 3.708 & .606 & \multirow{2}{*}{-6.298} & \multirow{2}{*}{.000} \\
\hline & female & 498 & 3.964 & .532 & & \\
\hline
\end{tabular}

Table 3. Significant moderation of ability between gender and the motivation components

\begin{tabular}{lccccc}
\hline Motivation component & $\mathrm{B}$ & $\mathrm{SE} \mathrm{B}$ & $\beta$ & $\mathrm{t}$ & 95\% CI For B \\
\hline Intrinsic motivation & -0.169 & 0.078 & -0.399 & $-2.170^{*}$ & $-0.322,-0.016$ \\
Self-determination & -0.286 & 0.084 & -0.611 & $-3.405^{* *}$ & $-0.451,-0.121$ \\
\hline
\end{tabular}

${ }^{*} \mathrm{p}<0.05,{ }^{* *} \mathrm{p}<0.001$

\section{FINDINGS AND DISCUSSION}

We first computed means and standard deviations of the components of the science motivation. In addition we computed $t$-values to examine the significance of the differences of the components scores between males and females. Table 2 shows means and standard deviations of the components of science motivation according to gender. It also shows $\mathrm{t}$-value for comparing means of each motivation component according to gender and the significance of the difference between the means.

Table 2 shows that female students had significantly higher scores in all the components of science motivation as well as the general motivation. These results are in contrast to researches that found that boys have higher scores for science motivation as Meece et al. (2006) who concluded that in general boys show more positive achievement-related beliefs in mathematics, science, and sports while girls show more positive beliefs in language arts and reading. The present research results are also in contrast to the results in Miller, Blessing and Schwartz (2006) who reported that females generally found science uninteresting and the scientific lifestyle (as perceived by them) unattractive. Glynn et al. (2011) also reported that men had higher self-efficacy than women. The present study results agree with studies that found that girls had higher scores in some components of science motivation than boys. One of these studies is that of Glynn et al. (2011) who reported that women had higher self-determination than men.

The present research results indicate that girls find science a subject in which they can realize themselves as learners, and that they are aware of science importance for their careers. Part of previous studies reported this direction of science motivation. Britner (2008) reported that in Earth Science classes, girls earned higher grades and reported stronger science self-efficacy. Moreover, the present research results could be due to the change in parents' attitudes about girls' ability in science and mathematics. Parents are a main factor in their children's values, practices, choices and academic effort (AdamutiTrache \& Andre, 2008; Lyons, 2006). In addition, according to the social cognitive model of academic choice developed by Eccles et al. (1983), both parents and teachers contribute to gender differences in motivation by different means as communicating different expectations and goals for boys and girls. It seems that parents' and teachers' attitudes and behaviours have developed into more favourable ones towards girls, which encouraged girls to develop positive inclination to and stronger motivation towards science.

The previous results were the basis for our verification of moderators between student's gender and science motivation.

\section{Student's Ability as a Moderator between Gender and Science Motivation Components}

To find whether student's ability moderates the relationship between gender and each one of the components of science motivation, we ran regression analysis which showed that student's ability moderates significantly the relationships between student's gender and each of the following motivation components: intrinsic motivation $\left(\mathrm{R}^{2}=0.005, \mathrm{~F}(832,1)=4.709, \mathrm{p}<0.001\right)$ and self-determination $\left(\mathrm{R}^{2}=0.012, \quad \mathrm{~F}(833,1)=11.592\right.$, $\mathrm{p}<0.01$ ). Table 3 shows the results of the moderation computations for each one of the above motivation components. These results are related to the interaction between student gender and ability (Gender*Ability) in step 2 of the regression analysis. 


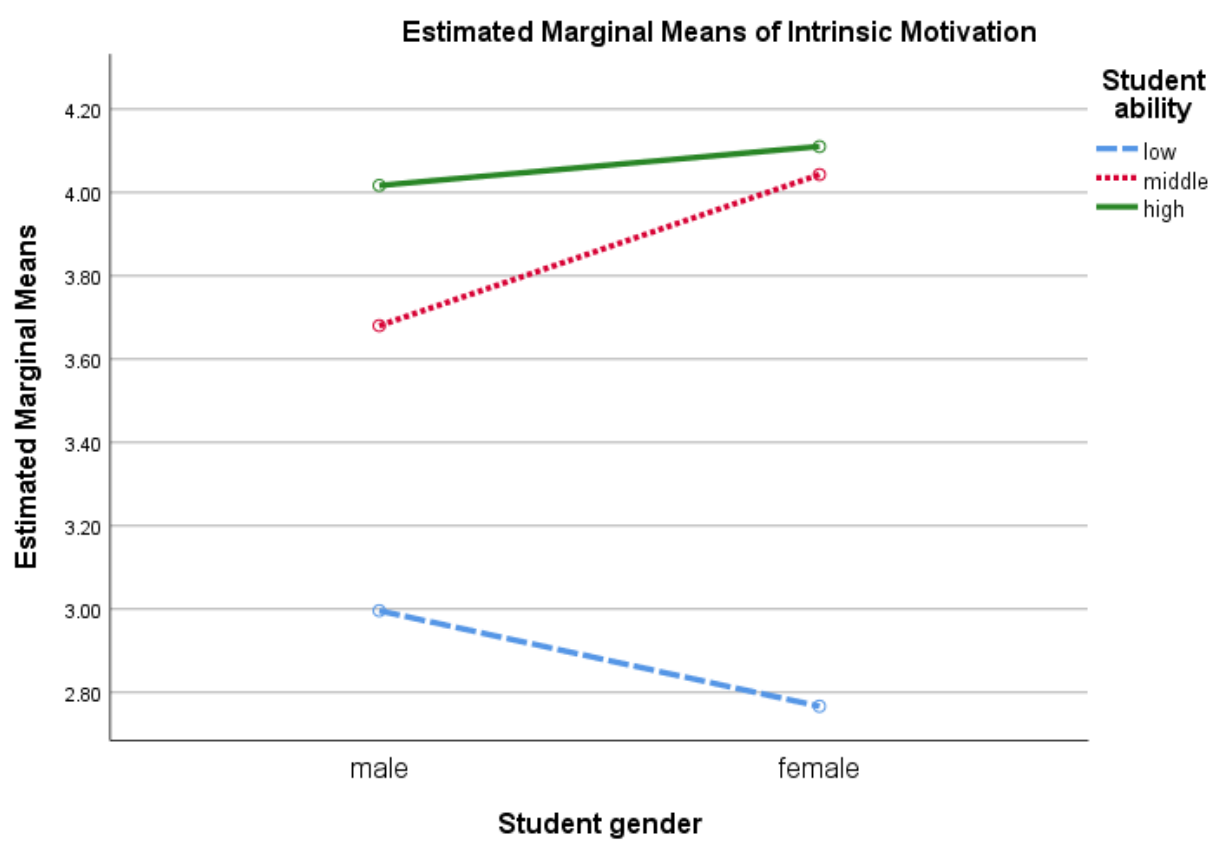

Figure 1. Ability as moderator between gender and student's intrinsic motivation

In addition, the regression equation for intrinsic motivation was: Intrinsic motivation $=2.127+$ $.617^{*}$ gender $+0.602^{*}$ ability $-0.169^{*}$ gender*ability (See appendix 1 for the appropriate regression table from the SPSS output). We plotted the effect of the interaction to understand its dynamics. Figure 1 shows this interaction.

We see that the trend is different for middle-ability and high-ability students; where the slope of the highability students' motivation is less steep than the slope of the middle-ability students' motivation. Thus, the graphs in Figure 1 indicate that the motivation difference between females and males is higher in the case of the middle-ability students. In addition, in the case of the low-ability students, males reported more motivation than males. The previous results confirm previous researches that reported that gender effects were moderated by the students' ability level, where in the low ability group only; boys reported a stronger mastery goal orientation than did girls (Meece \& Jones, 1996). Here, the high-ability, as well as the middle-ability, females reported a stronger intrinsic motivation than males. At the same time, the difference in the intrinsic motivation scores between female and male students is lower in the case of high-ability students than in the case of middle-ability students, which could indicate insignificant difference between high-ability females and males in intrinsic motivation. Computations showed that this is indeed the case: $\mathrm{t}=-1.614, \mathrm{p}=.107$.

A similar trend for the middle and high ability was found for self-determination regarding middle and high levels but different regarding the low level. Figure 2 shows the interaction in case of self-determination.
The same analysis above for intrinsic motivation applies here for self-determination, though here females have higher self-determination than males. The regression equation was: Self-determination $=1.384+$ $.977^{*}$ gender $+.875^{*}$ ability $-.286^{*}$ gender*ability (See appendix 2 for the appropriate regression table from the SPSS output). In all the scores of the components of science motivation, where student's ability moderates significantly between gender and motivation, the difference between female and male students was lower for high-achieving students than for middle- ability students.

In addition to the above significant moderations, the results of moderation analysis showed that ability does not moderate significantly between gender and each of the following motivation components: self-efficacy $(\beta=0.308, t(832)=1.747, p=0.081)$, career motivation $(\beta=-$ $0.106, \mathrm{t}(834)=-0.846, \mathrm{p}=0.398)$, grade motivation $(\beta=-$ $0.125, \mathrm{t}(833)=-1.591, \mathrm{p}=0.112)$ and general motivation $(\beta=-0.315, t(833)=-1.801, p=0.072)$. This means that for both middle- ability and high- ability students, motivation scores of females are higher than motivation scores of males, for three motivation components: selfefficacy, career motivation and grade motivation. These results point at the need to apply different methods to make both male and female science students motivated, in the previous components, to learn science. Researchers suggested science-motivating methods such as those suggested by Butler (2009, p. 1-2); namely making the science real (through working with themes and phenomena from the real world), making the science relevant (connected to student's age-appropriate lived experience and studied through encouraging posing questions by students), and making the science rigorous (through clarity and detailed instructions, as well as 


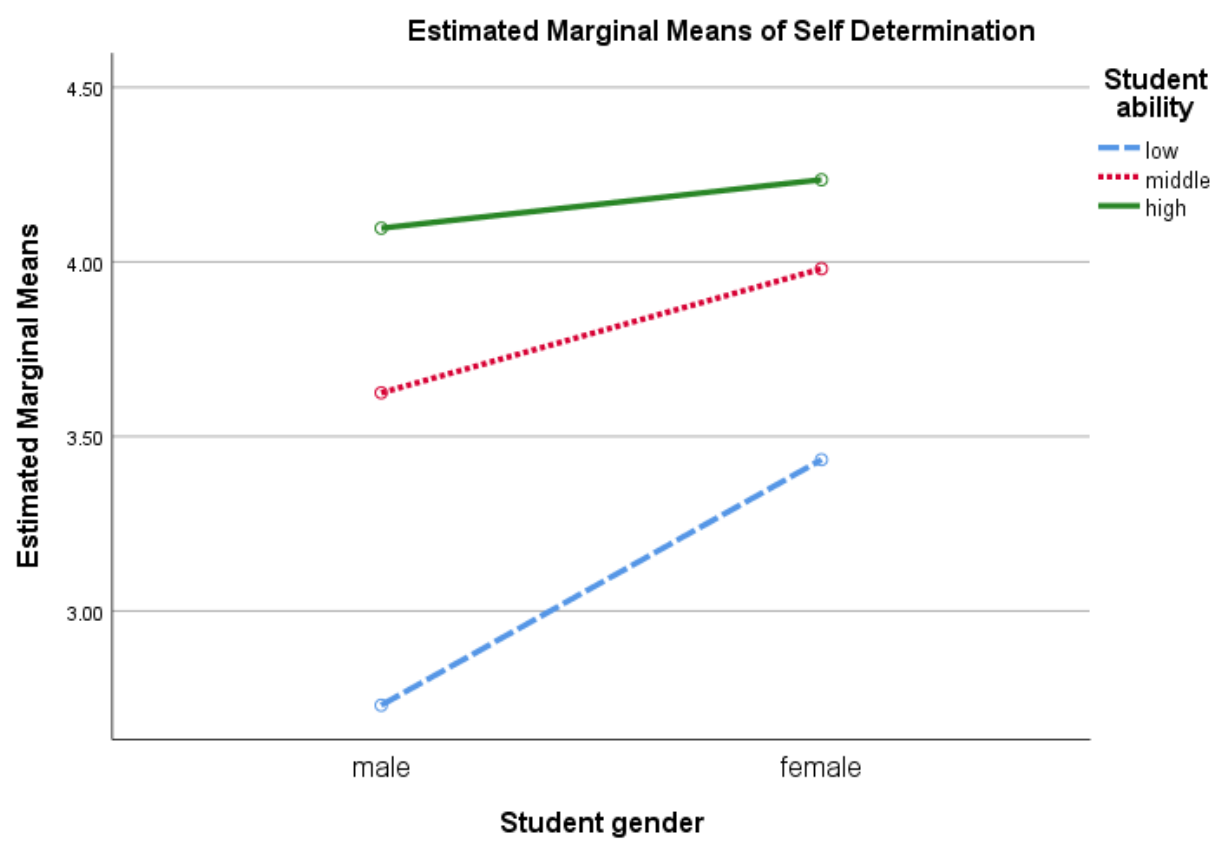

Figure 2. Ability as moderator between gender and student's self-determination

Table 4. Significant moderation results for the moderation of school level between gender and motivation components

\begin{tabular}{lccccc}
\hline Motivation component & $\mathrm{B}$ & $\mathrm{SE} \mathrm{B}$ & $\beta$ & $\mathrm{t}$ & $95 \%$ CI For B \\
\hline Intrinsic motivation & -0.155 & 0.061 & -0.365 & $-2.560^{*}$ & $-0.274,-0.036$ \\
Self-determination & -0.185 & 0.091 & -0.293 & $-2.028^{*}$ & $-0.364,-0.006$ \\
\hline
\end{tabular}

${ }^{*} \mathrm{p}<0.05,{ }^{* *} \mathrm{p}<0.001$

through assessment on multiple levels, as classroom tests and quizzes, and district, state, national and international standardized assessment).

\section{School Level as a Moderator between Gender and Science Motivation Components}

Regression analysis was run to examine whether school level moderates the relationship between gender and each one of the components of science motivation. The results showed that school level moderates significantly the relationships between student's gender and the motivation components: Self efficacy $\left(R^{2}=0.007\right.$, $\mathrm{F}(832,1)=6.552, \mathrm{p}<0.05)$, and career motivation $\left(\mathrm{R}^{2}=0.005\right.$, $\mathrm{F}(834,1)=4.112, \mathrm{p}<0.05)$. Table 4 shows the results of the moderation computations for each of the previous motivation component. These results are related to the interaction between student gender and school level (Gender*school level) in step 2 of the regression analysis.

In addition, the regression equation for self-efficacy was: self-efficacy $=3.178+0.438^{*}$ gender $+0.060^{*}$ schoollevel $-0.155^{*}$ gender*school-level (See appendix 3 for the appropriate regression table from the SPSS output). We plotted the effect of the interaction to understand its dynamics. Figure 3 shows this interaction.

Figure 3 shows that the trend is not the same for students at primary, middle and high school levels. At middle school level, self-efficacy is almost the same for males and females; i.e., no significant differences in self- efficacy exist, where the computations showed $t=0.317$, $\mathrm{p}=.751$. The same thing could be said about self-efficacy at high school, where computations showed: $t=-0.533$, $\mathrm{p}=.595$. At the same time at primary, females have significantly higher self-efficacy than males, where the computations showed $\mathrm{t}=-3.866, \mathrm{p}<.001$.

Furthermore, the regression equation for career motivation was: $2.990+0.716^{*}$ gender $+0.146^{*}$ schoollevel $-0.185^{*}$ gender* ability (See Appendix 4 for the appropriate regression table from the SPSS output). Plotting the effect of the interaction to understand its dynamics, it gave the interaction in this case, as in Figure 4.

Examining significance of the difference in career motivation between males and females in the different school levels, computations showed significant difference for high school: $t=-2.206, p<.05$ for high school, and insignificant differences for the other two school levels: $\mathrm{t}=-4.943, \mathrm{p}<.001$ for primary school, $\mathrm{t}=-$ $0.827, \mathrm{p}=.409$ for middle school and.

The previous results indicate that teachers and other educational agents like principals need to try to keep the motivation level of students at the middle school and high school as that at the primary school. Doing that, they should attempt to increase the motivation of males. In addition, the insignificant differences in self-efficacy motivation between males and females at the middle school means that efforts could be done to make these 


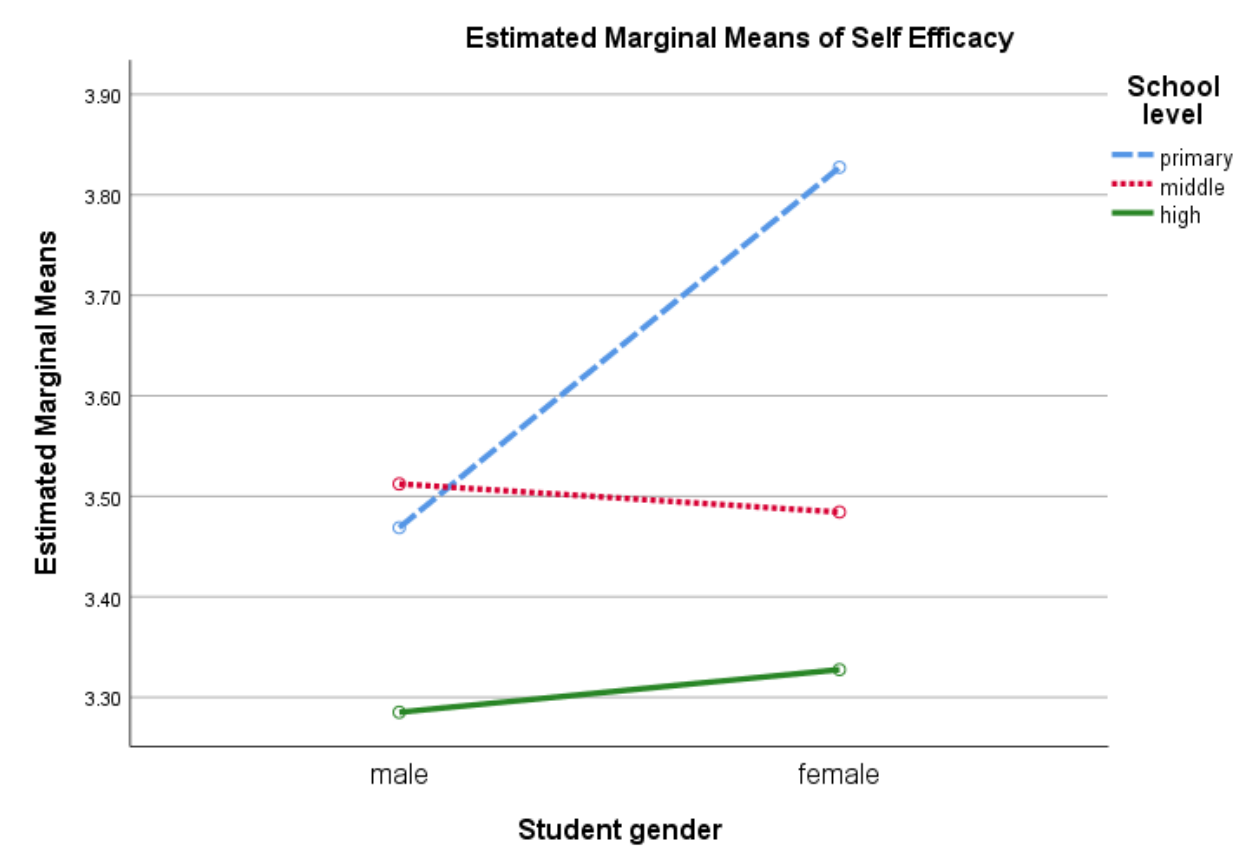

Figure 3. School level as moderator between gender and student's self-efficacy

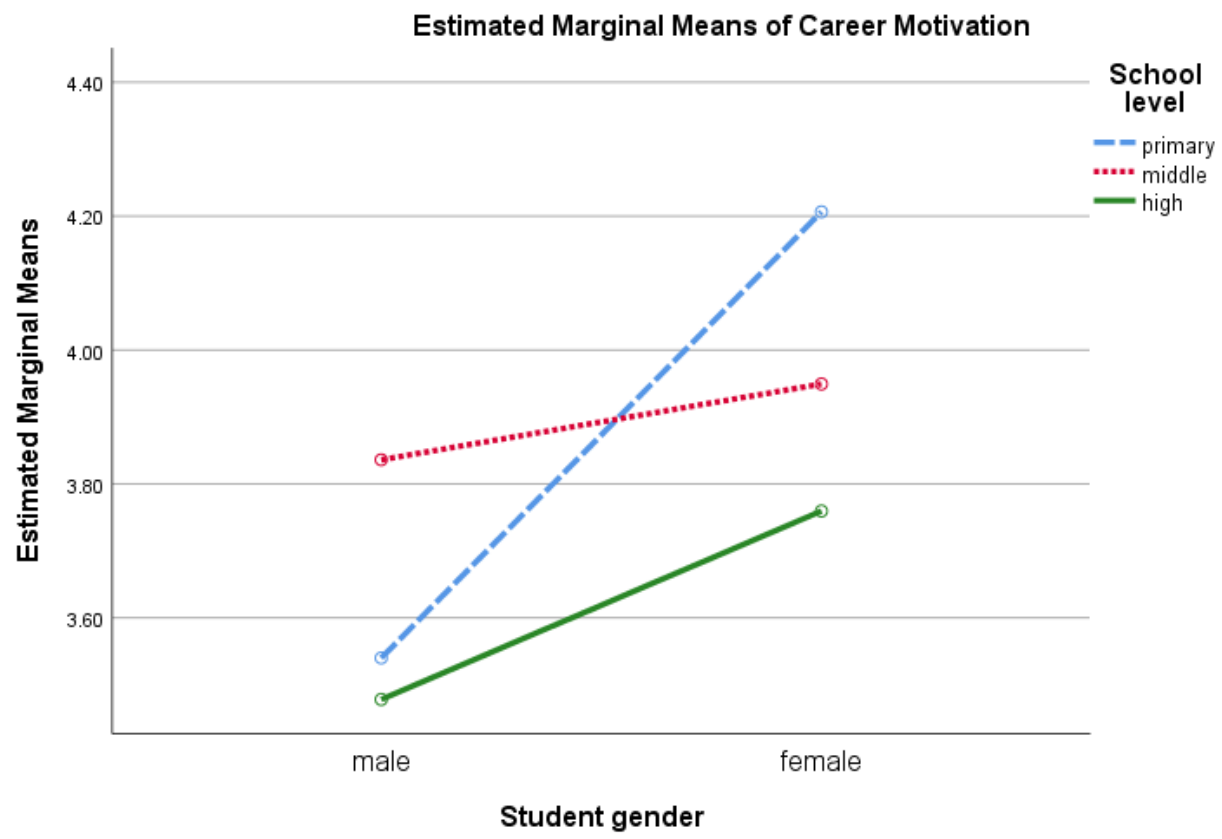

Figure 4. School level as moderator between gender and career motivation

differences stay insignificant also at the high school. What strengthen this claim are the findings of Britner (2008) that there were no gender differences in selfefficacy in Life Science or Physical Science.

The results of moderation analysis also showed that school level does not moderate significantly between gender and each of the following motivation components: intrinsic motivation $(\beta=-0.05, \mathrm{t}(832)=-0.39$, $\mathrm{p}=0.70)$, self-determination $\quad(\beta=-0.04, \mathrm{t}(833)=-0.36$, $\mathrm{p}=0.72)$, grade-motivation $\quad(\beta=-0.15, \mathrm{t}(833)=-1.25$, $\mathrm{p}=0.213)$ and general-motivation $(\beta=-0.20, \mathrm{t}(832)=-1.74$, $\mathrm{p}=0.081$ ). It could be concluded that students' motivation to learn science weakens with the advancement of school level, which points at the need to adopt different motivating science-teaching methods as authentic science experiences that would result in the strengthening of some motivation components (Hellgren \& Lindberg, 2017).

\section{Teacher's Gender as a Moderator between Student's Gender and Science Motivation}

Regression analysis was run to examine whether teacher's gender moderates the relationship between gender and each one of the components of science motivation. The results showed that teacher's gender moderates significantly the relationships between 
Table 5. Significant moderation results for the moderation of teacher's gender between student's gender and motivation components

\begin{tabular}{lccccc}
\hline Motivation component & $\mathrm{B}$ & $\mathrm{SE} \mathrm{B}$ & $\beta$ & $\mathrm{t}$ & $95 \%$ CI For B \\
\hline Intrinsic motivation & 0.297 & 0.133 & 0.475 & $2.238^{*}$ & $0.037,0.558$ \\
Self-determination & 0.483 & 0.209 & 0.493 & $2.315^{*}$ & $0.073,0.892$ \\
\hline
\end{tabular}

* $\mathrm{p}<0.05$

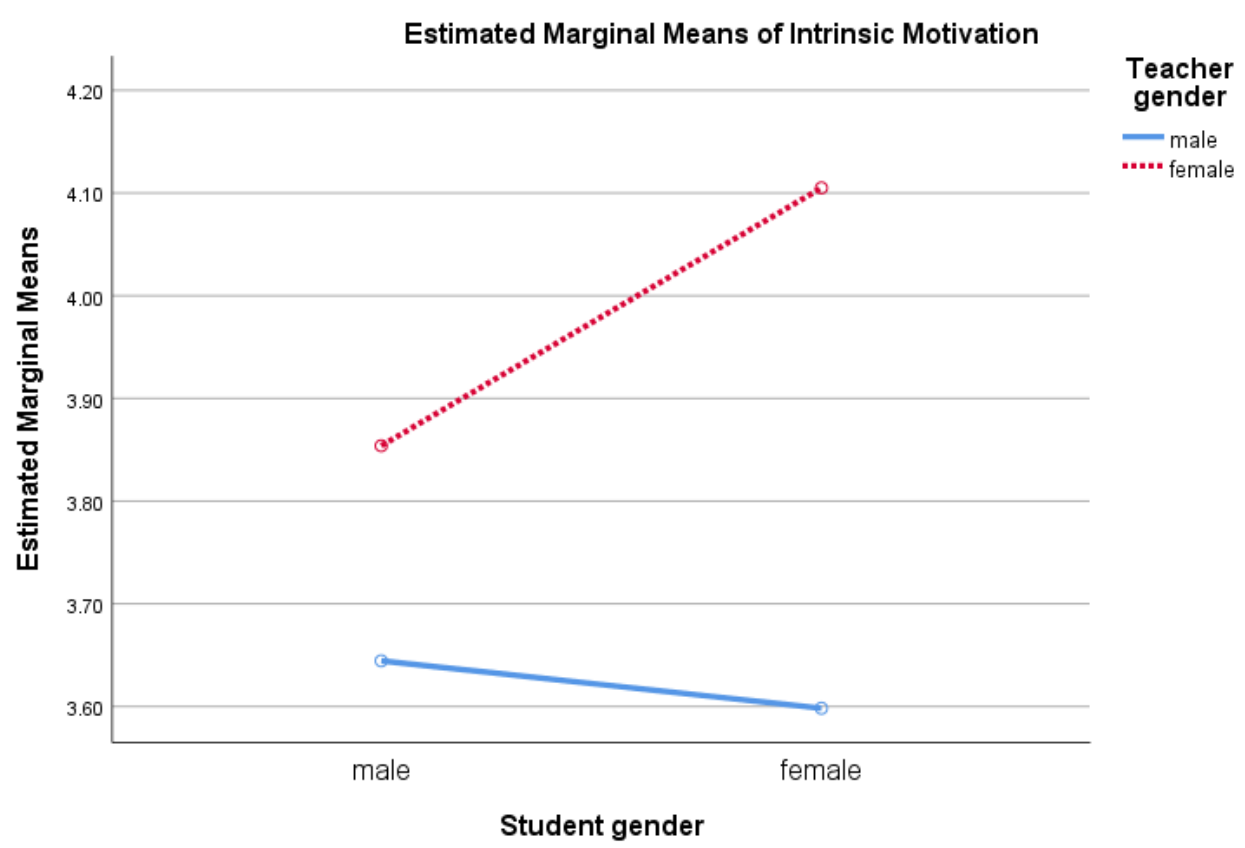

Figure 5. Teacher's gender as moderator between student's gender and her intrinsic motivation

student's gender and the motivation components: intrinsic motivation $\left(\mathrm{R}^{2}=0.006, \mathrm{~F}(831,1)=5.010, \mathrm{p}<0.05\right)$ and career motivation $\left(\mathrm{R}^{2}=0.006, \mathrm{~F}(833,1)=5.359\right.$, $\mathrm{p}<0.05)$. Table 5 shows the results of the moderation computations for each of the previous motivation component. These results are related to the interaction between student gender and school level (Gender*teacher's gender) in step 2 of the regression analysis.

In addition, the regression equation for intrinsic motivation was: Intrinsic motivation=3.88 + $.18^{*}$ student's gender $-0.12 *$ teacher's gender + $0.31^{*}$ student's gender*teacher's gender (See Appendix 5 for the appropriate regression table from the SPSS output). We plotted the effect of the interaction to understand its dynamics. Figure 5 shows this interaction.

Looking at the four combinations of student's gender and teacher's gender, Figure 3 shows that the combination 'female student'-'male teacher' resulted in the lowest intrinsic motivation between the four combinations, while the combination 'female student' 'female teacher' resulted in the highest motivation between the four.

Moreover, the regression equation for career motivation was: Career motivation $=4.014+$ $.564^{*}$ student's gender -0.386 *teacher's gender +
$0.483^{*}$ student's gender*teacher's gender (See appendix 6 for the appropriate regression table from the SPSS output). Plotting the effect of the interaction to understand its dynamics, it gave the interaction in Figure 6.

Figure 6 shows the same trend as in the case of intrinsic motivation, so the argument in that case applies here too. In addition to the significant moderations above, teacher's gender was not found to moderate significantly between student's gender and each one of the motivation components: self-efficacy $(\beta=-0.075$, $t(831)=-0.346, p=0.729)$, self-determination $(\beta=0.038$, $t(832)=182, \quad p=0.856)$, grade motivation $(\beta=0.111$, $t(832)=848, p=0.397)$, general motivation $(\beta=0.177$, $\mathrm{t}(828)=1.220, \mathrm{p}=0.095)$.

These results in the case of intrinsic motivation and career motivation are in contrast with other researches' results which indicated that male and female students exhibit higher levels of motivation when taught by male teachers (Varughese, 2017). More research is needed as the results of Varughese (2017) address science motivation in online environments. Moreover, the results in the present research are in contrast with the gender-invariant model which hypothesizes that academic motivation does not significantly vary as a function of teacher's gender. The present research results indicate that female teachers contribute to higher levels 


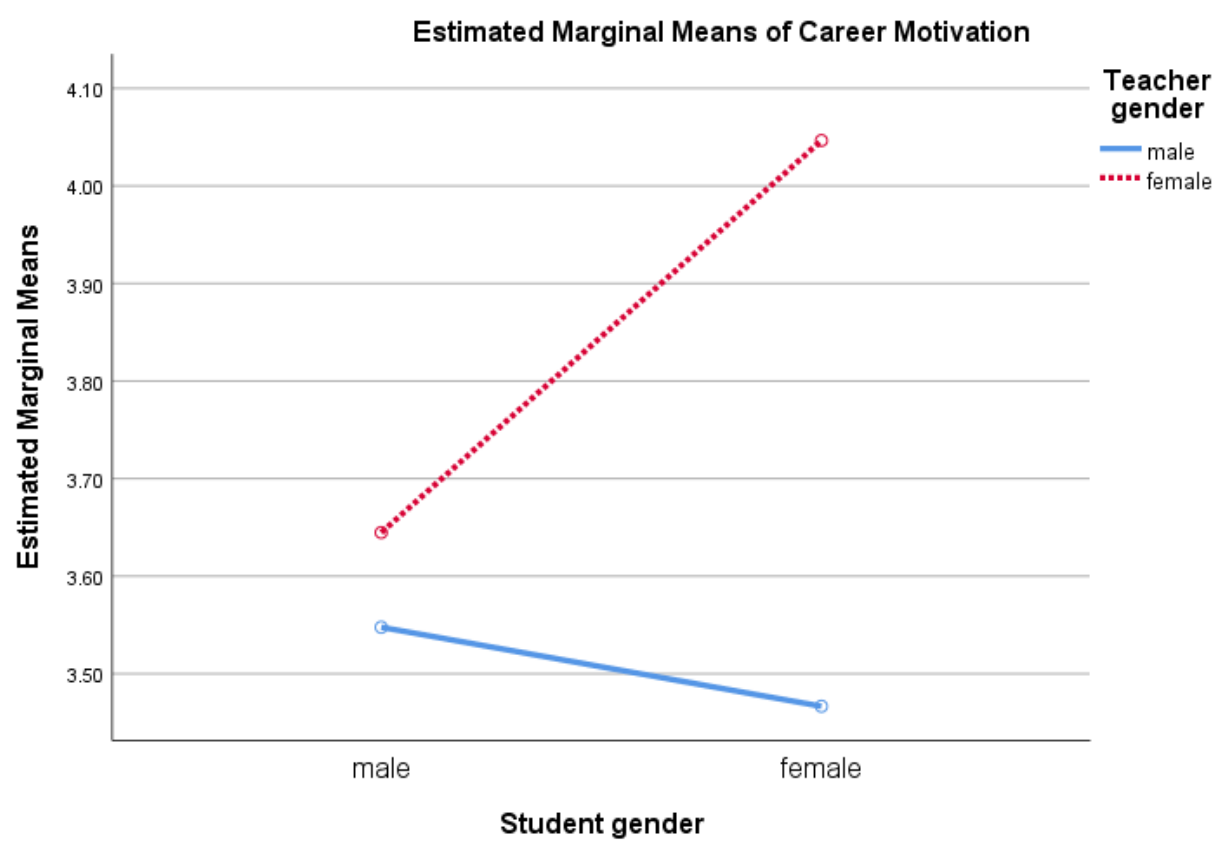

Figure 6. Teacher's gender as moderator between student's gender and her career motivation

of motivation for male as well as female students, but more for female students. In addition, the results in the case of the other three motivation components agree with gender-invariant model.

\section{CONCLUSIONS, RECOMMENDATIONS, AND LIMITATIONS}

The present research intended to study the moderation of ability, school level and teacher's gender between student's gender and science motivation. The research results indicated that each of the three variables moderated between student's gender and part of the components of science motivation. Ability moderated significantly between student's gender and each of intrinsic motivation, self-determination and general motivation, while school level moderated significantly between student's gender and each of self-efficacy and career motivation. At the same time, teacher's gender moderated significantly between student's gender and each of intrinsic motivation and career motivation. These results indicate that we need to take into consideration the three variables, as moderators between gender and student's motivation, when we come to take decisions regarding the science classroom. Taking into consideration the school level, we need to integrate different teaching methods in the science classroom, especially in the secondary school to make the learning of science in this school more appealing to the students from the five motivation aspects in which the present research is interested. These methods need to be diverse in order to fit both male and female science students, which could assist the learning of science in the secondary school for the two genders. Moreover, utilizing different teaching methods would support all ability -level students, and thus contribute to the ability issue for both genders. These different teaching methods could be achieved through applying them in different activities, as described above, or through a sequence of activities, as those suggested by Loukomies (2013, p. i): "The results of the research reveal that a teaching sequence that combines inquiry activities, industry site visits and writing tasks contains the potential to enhance students' feeling of relevance of their science studies and promote motivation and interest in school science". Such sequences would encourage science learning by students from different abilities and in different school levels due to their variance and relevance to students' life. The previous argument reminds of Dewey's focus on experience and inquiry as means for students' learning. Wong and Pughb (2014, p. 1) argue that "Dewey proposed that the mind evolved in response to problemsolving situations and, consequently, the mind functions best in practical, problem-solving situations". Hence, focusing on science experiences in problem-solving situation would result in positive consequences (Daher, 2009). Particularly, it would motivate students to learn science, and thus lessen the negative influence of the moderation of teachers' gender between educational predictors and science motivation as an outcome variable.

Furthermore, addressing the issue teacher's gender could be done through holding workshops for teachers to discuss the gender issue in science education and how to attempt to address this issue. The workshop should focus on the experiential aspect of science learning, where learning by experience lessens the effect of teacher's gender on students' learning as experience motivates students to learn (Albrecht \& Karabenick, 2018). Students' experience in learning science needs to 
broaden their understanding of the role of education in their lives (ibid).

In addition to the previous argument, we considered motivation depending on the social cognitive theory. This consideration, as argued before, makes it appropriate for considering relations and moderation of relations between variables related to personal characteristics, as the student's gender, and environmental variables as grade and teacher's gender. Here lies the advantages of the theoretical framework that the present study adopted. The limitations could be in the aspects that the theoretical framework did not or had little addressed, as autonomy in self-determination theory (Ryan \& Deci, 2000). Present research could address the present issue discussed in the research when it takes care of motivational factors that are not part of the present research.

Author contributions: All authors have sufficiently contributed to the study, and agreed with the results and conclusions.

Funding: No funding source is reported for this study.

Declaration of interest: No conflict of interest is declared by authors.

\section{REFERENCES}

Adamuti-Trache, M., \& Andres, L. (2008). Embarking on and Persisting in Scientific Fields of Study: Cultural capital, gender, and curriculum along the science pipeline. International Journal of Science Education, 30(12), 1557-1584. https://doi.org/ 10.1080/09500690701324208

Aktan, S. (2019). Investigation of classroom teaching, self-efficacy and motivation in social studies classrooms. International Journal of Research in Education and Science (IJRES), 5(2), 639-656.

Albrecht, J. R., \& Karabenick, S. A. (2018). Relevance for learning and motivation in education. The Journal of Experimental Education, 86(1), 1-10. https://doi.org /10.1080/00220973.2017.1380593

Areepattamannil, S., Freeman, J. G., \& Klinger, D. A. (2011). Influence of motivation, self-beliefs, and instructional practices on science achievement of adolescents in Canada. Social Psychology of Education: An International Journal, 14(2), 233-259. https:/ / doi.org/10.1007/s11218-010-9144-9

Bal-Taştan, S., Davoudi, S. M. M., Masalimova, A. R., Bersanov, A. S., Kurbanov, R. A., Boiarchuk, A. V., \& Pavlushin, A. A. (2018). The Impacts of Teacher's Efficacy and Motivation on Student's Academic Achievement in Science Education among Secondary and High School Students. Eurasia Journal of Mathematics, Science and Technology Education, 14(6), 2353-2366. https://doi.org/ 10.29333/ ejmste/ 89579

Bandura, A. (1997). Self-efficacy: The exercise of control. Freeman.
Bonney, C., Klemper, T., Zusho, A., Coppola, B. P., \& Pintrich, P. R. (2005). Student learning in science classrooms: What role does motivation play? In, S. Alsop (Ed.), Beyond Cartesian Dualism: Encountering Affect in the Teaching and Learning of Science (pp. 8397). Springer. https://doi.org/10.1007/1-40203808-9_7

Britner, S. L. (2008). Motivation in high school science students: A comparison of gender differences in life, physical, and earth science classes. Journal of Research in Science Teaching, 45(8), 955-970. https:/ / doi.org/10.1002/tea.20249

Butler, M. B. (2009). Motivating young students to be successful in science: Keeping it real, relevant and rigorous. National Geographic - Hampton-Brown. http:/ / www.ngspscience.com/profdev/monogra phs/SCL22-0419A_SCI_AM_Butler_lores.pdf

Chow, S. J., \& Yong, B.C. (2013). Secondary school students' motivation and achievement in combined science. US-China Education Review, 3(4), 213-228.

Chumbley, S. B., Haynes, C., \& Stofer, K. A. (2015). A Measure of Students' Motivation to Learn Science through Agricultural STEM Emphasis. Journal of Agricultural Education, 56(4), 107-122. https://doi.org/10.5032/jae.2015.04107

Chung, L.-Y., \& Chang, R.-C. (2017). The Effect of Gender on Motivation and Student Achievement in Digital Game-based Learning: A Case Study of a Contented-Based Classroom. Eurasia Journal of Mathematics, Science and Technology Education, 13(6), 2309-2327.

https:/ / doi.org/10.12973/eurasia.2017.01227a

Daher, W. (2009). Preservice teachers' perceptions of applets for solving mathematical problems: Need, difficulties and functions. Journal of Educational Technology \& Society, 12(4), 383-395.

Daher, W. (2011). Learning mathematics in the mobile phone environment: students' emotions. Journal of interactive learning research, 22(3), 357-378.

Daher, W., Anabousy, A., \& Jabarin, R. (2018). Metacognition, positioning and emotions in mathematical activities. International Journal of Research in Education and Science, 4(1), 292-303. https:/ / doi.org/10.21890/ijres.383184

Debacker, T. K., \& Nelson, R. M. (2000). Motivation to learn science: differences related to gender, class type, and ability. The Journal of Educational Research, 93(4), 245-254. https:// doi.org/10.1080/002206700 09598713

DeVellis, R. F. (2003). Scale development: Theory and applications (2nd Edn.). Sage.

Dionne, L., Reis, G., Trudel, L., Guillet, G., Kleine, L., \& Hancianu, C. (2012). Students' sources of motivation for participating in science fairs: an exploratory study within the Canada-wide science 
fair 2008. International Journal of Science and Mathematics Education, 10(3), 669-693. https:/ / doi.org/10.1007/s10763-011-9318-8

Eccles, J. S., Adler, T. F., Futterman, R., Goff, S. B., Kaczala, C. M., \& Meece, J. L. (1983). Expectancies, values and academic behaviors. In J. T. Spence (Ed.), Achievement and achievement motives (pp. 75146). Freeman.

Eccles, J. S., Wigfield, A., \& Schiefele, U. (1998). Motivation to succeed. In W. Danon \& N. Eisenberg (Eds.), The handbook of child psychology, social, emotional, and personality development. Wiley.

Freeman, T., \& Anderman, L. H. (2005). Changes in mastery goals in urban and rural middle school students. Journal of Research in Rural Education, 20(1), 1-13. http://jrre.vmhost.psu.edu/wpcontent/uploads/2014/02/20-1.pdf

Glynn, S. M., Brickman, P., Armstrong, N., \& Taasoobshirazi, G. (2011). Science Motivation Questionnaire II: Validation with Science Majors and Nonscience Majors. Journal of Research in Science Teaching, 48(10), 1159-1176. https://doi.org/ 10.1002/tea.20442

Glynn, S. M., Taasoobshirazi, G., \& Brickman, P. (2009). Science Motivation Questionnaire: Construct Validation with Nonscience Majors. Journal of Research in Science Teaching, 46(2), 127-146. https:/ / doi.org/10.1002/tea.20267

Hellgren, J. M., \& Lindberg, S. (2017). Motivating students with authentic science experiences: changes in motivation for school science. Research in Science \& Technological Education, 35(4), 409-426. https:/ / doi.org/10.1080/02635143.2017.1322572

Jacobs, J., Lanza, S., Osgood, D. W., Eccles, J. S., \& Wigfield, A. (2002). Ontogeny of children's selfbeliefs: gender and domain differences across grades one through 12. Child Development, 73(2), 509-527. https://doi.org/10.1111/1467-8624.00421

King, R. B. (2016). Gender differences in motivation, engagement and achievement are related to students' perceptions of peer-but not of parent or teacher-attitudes toward school. Learning and Individual Differences, 52, 60-71. https://doi.org/ 10.1016/j.lindif.2016.10.006

Lee, E. (2017). Effects of South Korean high school students' motivation to learn science and technology on their concern related to engineering. Educational Sciences: Theory \& Practice, 17(2), 549571. https:/ / doi.org/10.12738/estp.2017.2.0160

Lin, M.-H., Chen, H.-G., \& Liu, K.-S. (2017). A Study of the Effects of Digital Learning on Learning Motivation and Learning Outcome. Eurasia Journal of Mathematics, Science and Technology Education, 13(7), 3553-3564. https://doi.org/10.12973/ eurasia.2017.00744a
Loukomies, A. I. (2013). Enhancing Students' Motivation towards School Science with an Inquiry-based Site Visit Teaching Sequence: A Design-based Research Approach (Unpublished Ph. D. Dissertation). University of Helsinki, Helsinki, Finland. https://doi.org/ 10.5617 / nordina.854

Lyons, T. (2006). Different countries, same science classes: Students' experience of school science classes in their own words. International Journal of Science Education, 28(6), 591-613. https://doi.org/ 10.1080/09500690500339621

Martin, A. J. (2007). Examining a multidimensional model of student motivation and engagement using a construct validation approach. British Journal of Educational Psychology, 77(2), 413-440. https:/ / doi.org/10.1348/000709906X118036

Martin, A., \& Marsh, H. (2005). Motivating boys and motivating girls: Does teacher gender really make a difference? Australian Journal of Education, 49(3), 320-334. https:/ / doi.org/10.1177/000494410504900308

Meece, J. L., \& Jones, M.G. (1996). Gender differences in motivation and strategy use: Are girls rote learners? Journal of Research on Science Teaching, 33(4), 393-406. https:/ / doi.org/10.1002/(SICI)10982736(199604)33:4<393::AID-TEA3>3.0.CO;2-N

Meece, J. L., Glienke, B. B., \& Burg, S. (2006). Gender and Motivation. Journal of School Psychology, 44(5), 351373. https:/ / doi.org/10.1016/j.jsp.2006.04.004

Middleton, M. J., \& Midgley, C. (1997). Avoiding the demonstration of lack of ability: An underexplored aspect of goal theory. Journal of Educational Psychology, 89(4), 710-718. https:// doi.org/10.1037 / 0022-0663.89.4.710

Miller, P. H., Blessing, J. S., \& Schwartz, S. (2006). Gender differences in high-school students' views about science. International Journal of Science Education, 28(4), 363-381. https:/ / doi.org/10.1080/095006905 00277664

Ng, K. T., Soon, S. T., \& Fong, S. F. (2010). Development of a questionnaire to evaluate students' perceived motivation towards science learning incorporating ICT tool. Malaysian Journal of Educational Technology, 10(1), 39-55.

Nolen, S. B., \& Haladyna, T. M. (1990). Motivation and studying in high school science. Journal of Research in Science Teaching, 27(2), 115-126. https:/ / doi.org/10.1002/tea.3660270204

Obrentz, S. B. (2011). Predictors of Science Success: The Impact of Motivation and Learning Strategies on College Chemistry Performance (Unpublished doctoral dissertation). Georgia State University, Georgia, USA.

Ryan, R. M., \& Deci, E. L. (2000). Self-determination theory and the facilitation of intrinsic motivation, 
social development, and well-being. American Psychologist, 55(1), 68-78. https://doi.org/10.1037 /0003-066x.55.1.68

Say, S., \& Bag, H. (2017). The Evaluation of the Effect of a Newly Designed Computer Game on 7th Grade Students' Motivation Towards Science and Aggression. Eurasia Journal of Mathematics, Science and Technology Education, 13(8), 5379-5393. https:/ / doi.org/10.12973/eurasia.2017.00831a

Statistics Solutions. (2013). Data analysis plan: Moderation Analysis. https://www.statisticssolutions.com/ data-analysis-plan-moderation-analysis/

Taskinen, P. H., Schütte, K., \& Prenzel, M. (2013). Adolescents' motivation to select an academic science- related career: the role of school factors, individual interest, and science self-concept. Educational Research and Evaluation, 19(8), 717-733. https: / / doi.org/10.1080/13803611.2013.853620

Thomas, A. E. (2017). Gender differences in students' physical science motivation: Are teachers' implicit cognitions another piece of the puzzle? American Educational Research Journal, 54(1), 35-58. https:/ / doi.org/10.3102/0002831216682223
Tuan, H. L., Chin, C. C., \& Shieh, S. H. (2005). The development of a questionnaire to measure students' motivation towards science learning. International Journal of Science Education, 27(6), 634659.

https:/ / doi.org/10.1080/0950069042000323737

Varughese, Z. J. (2017). The influence of teacher gender on college student motivation and engagement in an online environment (Unpublished dissertation). Liberty University, Lynchburg, Virginia, USA.

Velayutham, S., Aldridge, J. M., \& Fraser, B. (2012). Gender differences in student motivation and selfregulation in science learning: a multi-group structural equation modeling analysis. International Journal of Science and Mathematics Education, 10(6), 1347-1368. https://doi.org/10.1007/s10763-0129339-y

Wong, D., \& Pughb, K. (2014). Dewey and the learning of science. In R. Gunstone (Ed.), Encyclopedia of Science Education. Springer Science Business Media. https: / / doi.org/10.1007/978-94-007-6165-0_518-2

\section{APPENDIX 1}

Moderation of Ability between Student's Gender and Intrinsic Motivation

\begin{tabular}{|c|c|c|c|c|c|c|c|}
\hline \multicolumn{8}{|c|}{ Coefficients $^{a}$} \\
\hline \multirow[t]{2}{*}{ Model } & \multicolumn{2}{|c|}{$\begin{array}{l}\text { Unstandardized } \\
\text { Coefficients }\end{array}$} & \multirow{2}{*}{$\begin{array}{c}\begin{array}{c}\text { Standardized } \\
\text { Coefficients }\end{array} \\
\text { Beta } \\
\end{array}$} & \multirow[t]{2}{*}{$\mathrm{t}$} & \multirow[t]{2}{*}{ Sig. } & \multicolumn{2}{|c|}{$\begin{array}{l}95.0 \% \text { Confidence Interval for } \\
\text { B }\end{array}$} \\
\hline & $\mathrm{B}$ & Std. Error & & & & Lower Bound & Upper Bound \\
\hline (Constant) & 2.777 & .120 & & 23.201 & .000 & 2.542 & 3.012 \\
\hline Gender & .187 & .047 & .132 & 4.022 & .000 & .096 & .279 \\
\hline Ability & .343 & .039 & .290 & 8.804 & .000 & .267 & .420 \\
\hline (Constant) & 2.127 & .323 & & 6.595 & .000 & 1.494 & 2.760 \\
\hline Gender & .617 & .203 & .436 & 3.034 & .002 & .218 & 1.016 \\
\hline Ability & .602 & .125 & .507 & 4.805 & .000 & .356 & .847 \\
\hline Gender * Ability & -.169 & .078 & -.399 & -2.170 & .030 & -.322 & -.016 \\
\hline
\end{tabular}

a. Dependent Variable: Intrinsic motivation

\section{APPENDIX 2}

Moderation of Ability between Student's Gender and Self Determination

\begin{tabular}{|c|c|c|c|c|c|c|c|}
\hline \multicolumn{8}{|c|}{ Coefficients $^{a}$} \\
\hline \multirow[t]{2}{*}{ Model } & \multicolumn{2}{|c|}{$\begin{array}{l}\text { Unstandardized } \\
\text { Coefficients }\end{array}$} & \multirow{2}{*}{$\begin{array}{c}\begin{array}{c}\text { Standardized } \\
\text { Coefficients }\end{array} \\
\text { Beta }\end{array}$} & \multirow[t]{2}{*}{$\mathrm{t}$} & \multirow[t]{2}{*}{ Sig. } & \multicolumn{2}{|c|}{$\begin{array}{l}95.0 \% \text { Confidence Interval for } \\
\text { B }\end{array}$} \\
\hline & $\mathrm{B}$ & Std. Error & & & & Lower Bound & Upper Bound \\
\hline (Constant) & 2.484 & .129 & & 19.186 & .000 & 2.230 & 2.739 \\
\hline Gender & .250 & .050 & .160 & 4.966 & .000 & .151 & .349 \\
\hline Ability & .437 & .042 & .333 & 10.358 & .000 & .354 & .520 \\
\hline (Constant) & 1.384 & .348 & & 3.979 & .000 & .701 & 2.067 \\
\hline Gender & .977 & .219 & .623 & 4.457 & .000 & .547 & 1.407 \\
\hline Ability & .875 & .135 & .666 & 6.474 & .000 & .609 & 1.140 \\
\hline Gender * Ability & -.286 & .084 & -.611 & -3.405 & .001 & -.451 & -.121 \\
\hline
\end{tabular}

a. Dependent Variable: Self determination 


\section{APPENDIX 3}

Moderation of School Level between Student's Gender and Self-Efficacy

\begin{tabular}{|c|c|c|c|c|c|c|c|}
\hline \multirow[t]{2}{*}{ Model } & \multicolumn{2}{|c|}{$\begin{array}{l}\text { Unstandardized } \\
\text { Coefficients }\end{array}$} & \multirow{2}{*}{$\begin{array}{c}\begin{array}{c}\text { Standardized } \\
\text { Coefficients }\end{array} \\
\text { Beta }\end{array}$} & \multirow[t]{2}{*}{$\mathrm{t}$} & \multirow[t]{2}{*}{ Sig. } & \multicolumn{2}{|c|}{$\begin{array}{c}95.0 \% \text { Confidence Interval for } \\
\text { B }\end{array}$} \\
\hline & $\mathrm{B}$ & Std. Error & & & & Lower Bound & Upper Bound \\
\hline (Constant) & 3.694 & .104 & & 35.638 & .000 & 3.490 & 3.897 \\
\hline Gender & .124 & .050 & .083 & 2.478 & .013 & .026 & .222 \\
\hline School level & -.194 & .029 & -.223 & -6.619 & .000 & -.251 & -.136 \\
\hline (Constant) & 3.178 & .226 & & 14.040 & .000 & 2.734 & 3.623 \\
\hline Gender & .438 & .132 & 295 & 3.308 & .001 & .178 & .698 \\
\hline School level & .060 & .103 & .069 & .582 & .561 & -.143 & .263 \\
\hline Gender * school level & -.155 & .061 & -.365 & -2.560 & .011 & -.274 & -.036 \\
\hline
\end{tabular}

a. Dependent Variable: Self efficacy

\section{APPENDIX 4}

Moderation of School Level between Student's Gender and Career Motivation

\begin{tabular}{|c|c|c|c|c|c|c|c|}
\hline \multicolumn{8}{|c|}{ Coefficients $^{a}$} \\
\hline \multirow[t]{2}{*}{ Model } & \multicolumn{2}{|c|}{$\begin{array}{l}\text { Unstandardized } \\
\text { Coefficients }\end{array}$} & \multirow{2}{*}{$\begin{array}{c}\text { Standardized } \\
\text { Coefficients } \\
\text { Beta }\end{array}$} & \multirow[t]{2}{*}{$t$} & \multirow[t]{2}{*}{ Sig. } & \multicolumn{2}{|c|}{$\begin{array}{l}95.0 \% \text { Confidence Interval for } \\
\text { B }\end{array}$} \\
\hline & $\mathrm{B}$ & Std. Error & & & & Lower Bound & Upper Bound \\
\hline (Constant) & 3.604 & .155 & & 23.180 & .000 & 3.299 & 3.909 \\
\hline Gender & .342 & .075 & .155 & 4.555 & .000 & .195 & .489 \\
\hline School level & -.156 & .044 & -.121 & -3.562 & .000 & -.243 & -.070 \\
\hline (Constant) & 2.990 & .340 & & 8.786 & .000 & 2.322 & 3.658 \\
\hline Gender & .716 & .199 & .324 & 3.596 & .000 & .325 & 1.106 \\
\hline School level & .146 & .155 & .113 & .939 & .348 & -.159 & .451 \\
\hline Gender * School level & -.185 & .091 & -.293 & -2.028 & .043 & -.364 & -.006 \\
\hline
\end{tabular}

a. Dependent Variable: Career Motivation

\section{APPENDIX 5}

Moderation of Teacher's Gender between Student's Gender and Intrinsic Motivation

\begin{tabular}{|c|c|c|c|c|c|c|c|}
\hline \multicolumn{8}{|c|}{$\begin{array}{c}\text { Coefficients }^{\mathbf{a}} \\
\end{array}$} \\
\hline \multirow[t]{2}{*}{ Model } & \multicolumn{2}{|c|}{$\begin{array}{l}\text { Unstandardized } \\
\text { Coefficients }\end{array}$} & \multirow{2}{*}{$\begin{array}{c}\begin{array}{c}\text { Standardized } \\
\text { Coefficients }\end{array} \\
\text { Beta } \\
\end{array}$} & \multirow[t]{2}{*}{$\mathrm{t}$} & \multirow[t]{2}{*}{ Sig. } & \multicolumn{2}{|c|}{$\begin{array}{l}\text { 95.0\% Confidence Interval for } \\
\text { B }\end{array}$} \\
\hline & $\mathrm{B}$ & Std. Error & & & & Lower Bound & Upper Bound \\
\hline (Constant) & 2.959 & .141 & & 21.057 & .000 & 2.684 & 3.235 \\
\hline Student gender & .206 & .048 & .146 & 4.310 & .000 & .112 & .300 \\
\hline Teacher gender & .358 & .067 & .182 & 5.380 & .000 & .227 & .489 \\
\hline (Constant) & 3.779 & .392 & & 9.642 & .000 & 3.009 & 4.548 \\
\hline Student gender & -.343 & .250 & -.243 & -1.374 & .170 & -.834 & .147 \\
\hline Teacher gender & -.088 & .210 & -.045 & -.418 & .676 & -.500 & .324 \\
\hline Student gender * Teacher gender & .297 & .133 & .475 & 2.238 & .025 & .037 & .558 \\
\hline
\end{tabular}

a. Dependent Variable: Intrinsic Motivation 
APPENDIX 6

Moderation of Teacher's Gender between Student's Gender and Career Motivation

\begin{tabular}{|c|c|c|c|c|c|c|c|c|}
\hline \multicolumn{9}{|c|}{$\begin{array}{c}\text { Coefficients }^{a} \\
\end{array}$} \\
\hline \multirow{2}{*}{\multicolumn{2}{|c|}{ Model }} & \multicolumn{2}{|c|}{$\begin{array}{l}\text { Unstandardized } \\
\text { Coefficients }\end{array}$} & \multirow{2}{*}{$\begin{array}{c}\text { Standardized } \\
\text { Coefficients } \\
\text { Beta }\end{array}$} & \multirow[t]{2}{*}{$\mathrm{t}$} & \multirow[t]{2}{*}{ Sig. } & \multicolumn{2}{|c|}{$\begin{array}{c}95.0 \% \text { Confidence Interval for } \\
\text { B }\end{array}$} \\
\hline & & $\mathrm{B}$ & Std. Error & & & & Lower Bound & Upper Bound \\
\hline & (Constant) & 2.679 & .221 & & 12.095 & .000 & 2.244 & 3.114 \\
\hline & Student gender & .327 & .075 & .148 & 4.336 & .000 & .179 & .476 \\
\hline & Teacher gender & .342 & .105 & .112 & 3.274 & .001 & .137 & .547 \\
\hline & (Constant) & 4.014 & .618 & & 6.499 & .000 & 2.802 & 5.227 \\
\hline & Student gender & -.564 & .392 & -.255 & -1.437 & .151 & -1.334 & .206 \\
\hline & Teacher gender & -.386 & .331 & -.126 & -1.164 & .245 & -1.036 & .265 \\
\hline & Student gender * Teacher gender & .483 & .209 & .493 & 2.315 & .021 & .073 & .892 \\
\hline
\end{tabular}

a. Dependent Variable: Career Motivation 